\title{
Inquiry Into the Moroccan Private Equity Industry: A Proposal of an Adapted Value Creation Framework
}

\author{
Taoufik A. Taleb ${ }^{1} \&$ Abdessadeq Sadqi ${ }^{2}$ \\ ${ }^{1}$ Groupe Institut Supérieur de Commerce et d'Administration des Entreprises (ISCAE), Casablanca, Morocco \\ ${ }^{2}$ Ecole Nationale de Commerce et de Gestion, Hassan 1st University, Settat, Morocco \\ Correspondence: Taoufik A. Taleb, Groupe ISCAE, Casablanca, 8114 Route de Nouacer, Casablanca, Morocco. Tel: \\ 212-6614-63511.
}

Received: December 3, 2019

Accepted: December 31, 2019

Online Published: March 16, 2020

doi:10.5430/ijfr.v11n2p1

URL: https://doi.org/10.5430/ijfr.v11n2p1

\begin{abstract}
The Private Equity (PE) activity in Morocco has received so little attention until now. Aside from the professional association of PE in Morocco and other professional bodies concerned with the topic, the literature stream exploring the generation of value creation during a PE transaction is quite inexistent.

The proposed paper is considered as the first attempt to tackle the value generation within a Private Equity transaction in the Moroccan context. We attempt during this paper to present a conceptual analysis of how PE firms may generate value on their portfolios level. Since data is a scarce resource in this field and especially in the context of emerging countries, we propose for this explanatory study to use the semi constructed interview with four major PE firms in the Moroccan landscape, which represents 50\% of the PE transactions that occurred in the last three years, in order to (i) understand the general partners (GPs) decision-making process for a given transaction and (ii) explain what are the main value generation levers that are intended to be made into practice in order to maximize the value in a given transaction.
\end{abstract}

Keywords: private equity firms, value creation, SME, general partners, private equity funds, selection criteria

\section{Introduction}

\subsection{Introduce the Problem}

In the last two decades, the Moroccan private equity industry has experienced important development regarding its position in the Moroccan economic landscape. More than a simple financial intermediary, this emerging actor has become known as an entrepreneur by a delegation of many Small and Medium Entreprises (SMEs).

In contrast with PE firms acting in developed economies, the Moroccan practice has shown resilience in the aftermath of the financial distress in 2008 (AMIC, 2010). While the debate abroad shed light on information disclosure, PE firms unethical process of ripping a part companies, etc., the local debate on PE firm was slanted towards its potential as an incubator of the Moroccan SMEs and especially high potential SMEs, known as "Gazelles". Despite the importance and controversy of these public debates, so little research has been tackling this relationship (Rohamad \& Idrissi, 2005, Makhroute \& Herrati, 2019). As the main stream of literature has tackled this association in basics ways, we believe that the most predominant (and interesting) one is the one highlighting the contribution of PE firms to high potential SME, from the perspective of value generation.

Value generation for SMEs in a PE transaction, is considered as the core objective by PE firms. Through inclusive actions, the latter call up all value generation lever, that contribute to the process. Berg and Gottschalg (2003), argued that the concept of value generation is twofold: it encompasses the levers that contribute to the value creation and the levers that form the value capturing. To understand the levers contribution in these transactions and how Moroccan $\mathrm{PE}$ firms rely on them to generate value, it is imperative to understand the Moroccan PE industry investment process and to understand and explain the rational motivation that entails a PE investment and how PE firms address the value generation through the related levers.

This research is considered as the first exploratory study, that aims through qualitative tools (i) to give a first understanding of the PE Moroccan practice, (ii) to fill the literature gap that fails to describe the relationship between 
the rational motivations that drive PE firms investments and the value creation process and (iii) propose an adhoc framework that can facilitate the understanding of organic composition of created value in a Moroccan PE transaction. We used semi constructed interviews with 4 PE firms general partners (which consists of active PE firms, representing $50 \%$ of the PE Moroccan transaction in the last three years), who were asked based on an interview guide about the insight that could help us contextualize a literature that so far was adapted to developed countries.

This paper contribution is threefold. First it gives the PE practitioners, a clearer view on what are the rational motivation of PE firms to invest in general and especially in a Moroccan context.

Second, we then try to link between the sphere of PE investment motivations and the sphere of PE value creation process. This will allow us to uncover how the Moroccan PE industry conceive value creation on the SMEs levels, which have not been yet investigated.

Third, this route offers also an ad hoc analysis to provide a critical view of the classical PE value conceptual framework and consider a timely inclusive approach of the value creation process in the Moroccan PE activity.

The reminder of this paper proceeds as follows: at first, we review relevant literature about rational motives of a PE investment, we pinpoint the links between the whole investment process and the value creation process in a PE transaction. Second, we propose to undertake our research question. Third, the research methodology is presented and explained. Finally, the fourth step consists in presenting empirical results and discussion of the key findings.

\section{Literature Review}

\subsection{Definition and Taxonomy in the Moroccan Context}

Although the private equity practice is no longer to be defined, defining it again in a Moroccan context may seem relevant to better understand this phenomenon. In general, a Private Equity investment may be defined as "investing in securities through a negotiated process", as the majority of Private Equity investments are in unquoted companies" (Loos, 2005). It's a form of alternative investment that presents an active value added to the invested company, through an active management. Kaplan and Stromberg (2009) have also defined these kind of transactions as "In $a$ typical leveraged buyout transaction, the private equity firm buys majority control of an existing or mature firm. This arrangement is distinct from venture capital firms that typically invest in young or emerging companies, and typically do not obtain majority control".

Through these two definitions, we can already see that a PE transaction is characterized by an over the counter negotiation process that aims (in general) to take a majority share capital in an unquoted company. Depending on the stage of development and the transaction structuring, the PE firm can employ a leveraged buyout mechanism to fulfill the acquisition. Last thing, it should be noted that a distinction needs to be made between a PE firm and a venture capital firm. The latter is a similar firm that concerns only young emerging companies, known as start-ups.

With that in mind, these definitions are likely to be more adapted to developed economies than an emerging or in a transition economy, since (i) all these studies were studying the PE phenomenon in a western context and (ii) regarding the time when the studies were made, the PE industry had just started in Morocco. These facts lead us to the necessity of an appropriate definition to the Moroccan PE practice. Current local literature about the Moroccan PE definition revolves around the definition of AMIC (Note 1), which define it as: "financial activity consisting of acquiring equity interests (in the form of share capital, convertible or non-convertible debt securities and shareholdors current account) for a fixed period in unlisted companies in need of equity or quasi-equity, The terms "venture capital" and "capital investment" are sometimes used interchangeably. However, it seems more judicious to distinguish these two notions. Here, the term "Capital Investment" will be used as a generic term while the term "Venture Capital" will be reserved for financing companies in creation" (Note 2).

On the other hand, an interesting definition of the PE investment in the Moroccan context may be presented "all temporary and minority shareholding activities in unlisted companies in order to generate capital gains at a later stage ... Private equity is an equity transaction that is profitable only in the growth and profitability of the acquired company. Private equity is a medium or long-term investment in which the investor makes an active contribution to the success of companies, accompanying their growth to become the leading companies in their sector, with a view to facilitating their IPO or their takeover by a third party." (Note 3) (Rhomad et Idrissi 2005).

Based on these definitions above, we can present the following similarities and dissimilarities: 
Table 1. Similarities and dissimilarities between the Moroccan PE taxonomy and the international taxonomy

\begin{tabular}{ll}
\hline Similarities & Dissimilarities \\
\hline $\begin{array}{l}\text { Distinction between VC and PE } \\
\text { firms }\end{array}$ & $\begin{array}{l}\text { Moroccan PE practice does not include systematically debt to acquire } \\
\text { a company }\end{array}$ \\
\hline Mid and long term investment & Moroccan PE practice does not target systematically a majority stake. \\
\hline & $\begin{array}{l}\text { International PE practice definitions does not put a distinction } \\
\text { between a PE transaction and a LBO. }\end{array}$ \\
\hline $\begin{array}{l}\text { Moroccan PE investment definition is focused on supporting the } \\
\text { growth of the invested companies. }\end{array}$ \\
\hline
\end{tabular}

Source: Author

These differences in definitions and taxonomy, may indicate that there are some particularities that need to be taken into consideration while considering studying the PE industry in the Moroccan context.

Unlike the traditional literature stream related to study performance, value creation or any other topic related to PE firms, we think that the conundrum of the Moroccan PE practice needs to be taken differently, regarding the third parties that interfere in this process.

The most crucial third party that is tightly related to how value creation is created through this kind of investment is the invested company (Caselli, 2009). Therefore, in the light of this fact, an important question raises: "How do PE firms in general (and Moroccan PE firms in particular), choose their targeted companies?"

\subsection{An Inquiry to Understand the Rational Motivations Behind Selecting a Target}

To answer our question, it is most important to understand the rational motivations that leads the actions of a PE firm while considering an investment. Before dwelling on the selection criteria that relates directly to the invested companies, we need to consider the party as whole and go back to the inception of the investment.

At the most aggregate level, it seems that PE firms give an importance to the host economy and its legal framework before investing in a given company (Bernoth, 2010). When talking about economy and legal framework, we need to distinguish three elements that influence the PE firm activity: (i) the existence of an efficient work market, (ii) the nature of tax and legal background and (iii) the economic performance of the host economy (Cervaux, 2015). These three components play a major role in attracting PE investments and offers them a propitious ground to be fully efficient while conducting their value creation process.

The existence of an efficient work market will allow the general partners (GPs) to go through corporate restructuring process over the targeted company, including the management change and corporate governance enhancement (Millson \& Ward, 2005). Any discrepancies in this market will hamper the workforce fluidity and thus, alter at the end the PE superior corporate governance (Jensen, 1989a).

As for the legal and taxation background of the host country, it has several impacts on the PE investment decision. On the same page as the famous economist Laffer quote states: "too many taxes kill taxes", PE funds need an appropriate taxation system, that can allow them to function properly. In relation with the Moroccan context, the Moroccan legal and taxation background presents an interesting framework (i.e. law 41-05). However, taxation framework lack incentive to encourage PE firms activity. On the other hand, Groh and Lieschtenstein (2011), argue that the main preoccupation of limited partners (LPs) can be summarized in four points: (i) the extent to which private property is protected, (ii) existence of a local competent and qualified GPs team, (iii) quality of management and entrepreneurs in the host country and (iv) the degree of corruption.

Finally, the attractivieness of the host economy measured through the GDP and GDP per capita, etc. are considered before making the investment decision. Good indicators may reveal that the country has an interesting potential in terms of population and power purchase, two fundamental macroeconomic considerations while considering an investment in a market. Lounes (2012) argue that $1 \%$ increase (or decrease) in the GDP can induce an IRR increase (or decrease) by $3.3 \%$ of PE firm investment, Sic Stantibus Celeris Paribus. In addition, it has been proven that (i) a good economy can be sensed through efficient financial markets (Irrmann, 2008) and (ii) there is a positive correlation between financial markets dynamics and the PE funds. In fact, dynamic financial markets can present better perspectives to PE transaction exits which are vital to the success of these operations (Boufalah, 2018). 
Once the extrinsic motivations presented, the PE firms posess intrinsic motivations that relate to their nature, investment strategy, internal organization and footprint. The PE profile can influence materially the investment decision process. For instance, a PE firm specialized in transmission (LBO) transactions should be more likely to invest in mature companies that can assure stable Free Cash Flows to reimburse the debt service and avoid bankruptcy risk (Jensen, 1989a, Loos, 2005).

Whatsoever the PE internal organization, the third layer that is considered while investing in a company within a PE transaction is the existence of agency problem. The seminal article of Jensen (1989a) provide evidence that support the PE firm's superior governance and presents them as an appropriate answer that can alleviate the agency costs in an organization. In other terms, PE firms would be more encouraged to invest in a company that can present a high potential and competitive advantage, but with a weak corporate governance with principal and agent issues. However, it is worthy to note that this vision is more adopted in the developed economies rather than economies in transition, such as Morocco. Since the Moroccan economy landscape is more likely populated with SMEs and especially family's SMEs (Rohamad and Idrissi, 2005), the agency problems tend to be less overriding due to the confusion between the status of shareholder and manager (Dawson, 2011). Nevertheless, the agency problems can still subsist between the entrepreneur (or shareholder) and the other key men that can have more information and thus create an asymmetry information situation.

Rikato (2014) argues that the GPs need to have the capacity to flair that a potential targeted company have important room for organizational and operational improvement. Notwithstanding, the results of his study shows also that these potential targeted companies may not have the same growth experience as they were not backed up with the PE firms, which spotlights the role of the GPs.

The fourth and last layer can be presented as the direct criteria of the targeted companies. Block, Fisch, Vismara and Andres, (2019), confirms that a pattern can be found regarding this practical phase of the company development and the PE firms internal organization. Based on an innovative methodology that use a conjoint analysis, the authors propose to synthesize the criteria regardless PE firms types into the following relative importance:

i. Revenue growth (23.4\%);

ii. Value added of the product / service (20.4\%);

iii. Track record of management team (15.7\%);

iv. International scalability (13\%);

v. Profitability (11.8\%);

i. $\quad$ Business model (8.3\%); and finally

vii. Current investors (7.3\%).

As presented above, PE firms put into the heart value creation as a major consideration in the selection process, that lead the way to the right targeted company. To sum up, we propose the following pyramid that emphasis, the four layers of rational motivations that could explain the selection process.

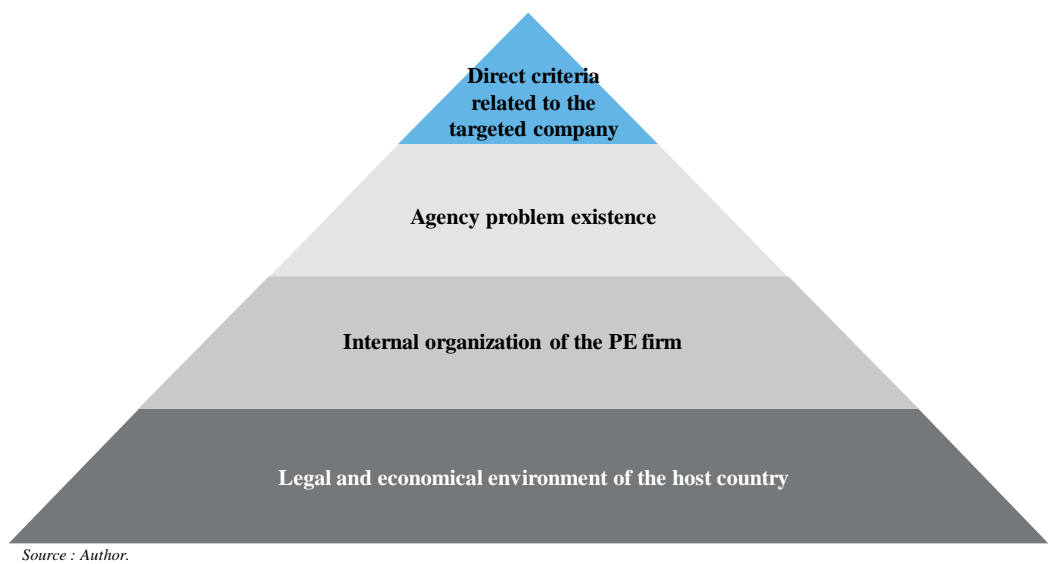

Figure 1. Pyramid of PE firms rational investment incentives 


\subsection{PE Firm Investment Process and Value Creation Process}

As already mentioned above, the GPs keep focusing on linking between the selection criteria dimension and the value creation process dimension. When we look up the investment process, the result is a composition of a mix of criteria (layers) that work together in a complex managerial process (Gompers, Gornall, Kaplan \& Strebulaev, 2019). When referring to our context, PE firms investment decisions are mostly driven by supporting SMEs growth plans (Rohamad \& Idrissi, 2005, Caselli, 2009, Taleb, 2019).

The value generation process has been typically analyzed through the perspective of equity investors in a PE transaction (Berg \&Gottschalg, 2003). However, little did these researches present that this perspective is a connected vessel to the features of the targeted companies. Since basically the value is generated at the company level, we must highlight that the equity investor value perspective is only the reflection of the value at the company level and at a given moment. When taking a closer look to it, we can consider that the targeted companies characteristics (e.g. financial performance, management team quality, etc.) are the based form of value generation levers or can pinpoint to them in certain cases. Consequently, we propose the following framework to understand the link that underly the two processes.

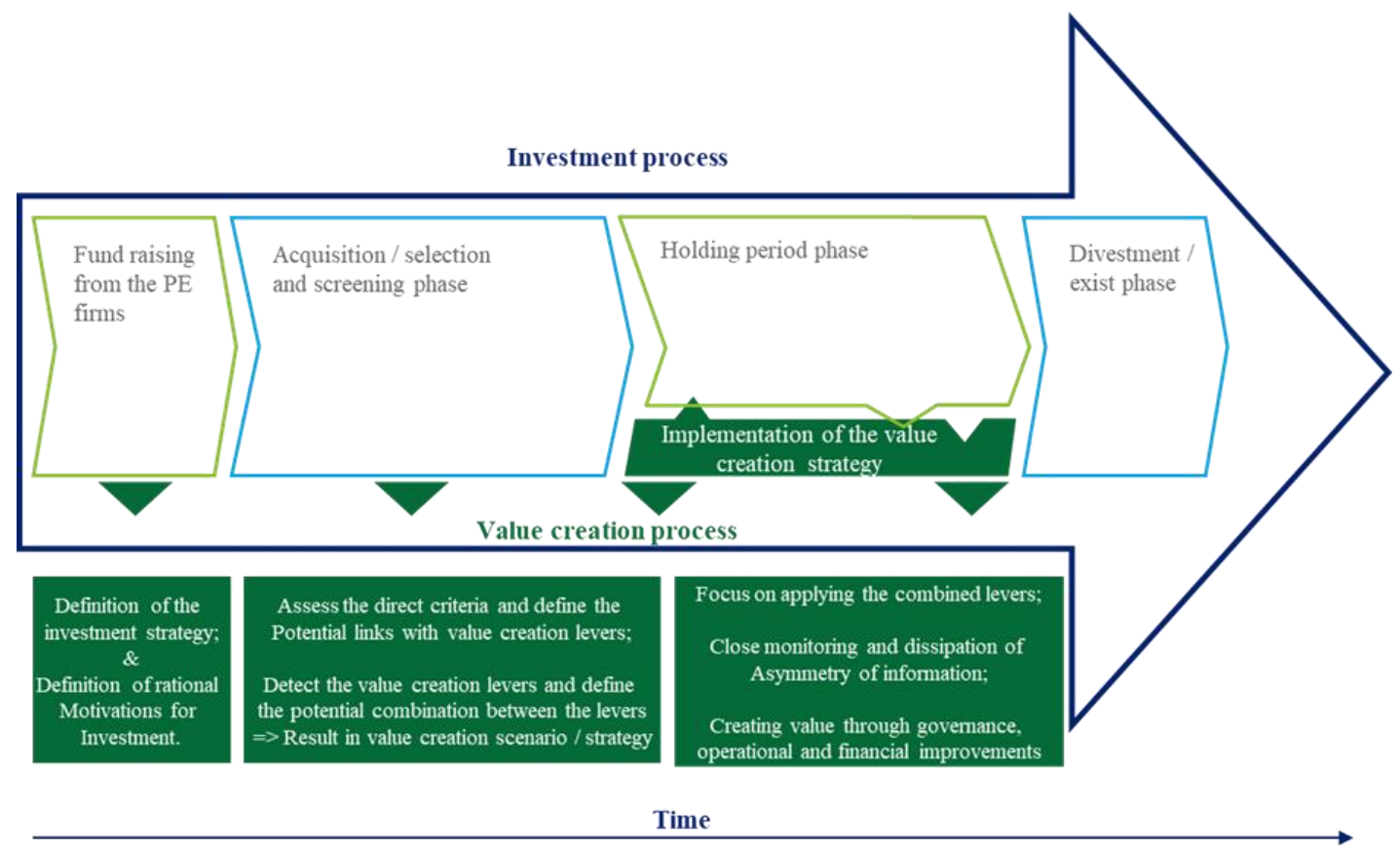

Source: Author:

Figure 2. Linking framework between PE investment process and PE value creation process

Now that we've shown that the PE firm investment process is intimately correlated with the value creation process within these transactions, let's get deep into the rabbit hole and try to emphasis the value creation levers that participate in a value creation process.

\subsection{Emphasis of Value Levers Through That Process}

Many researches tried to present a conceptual framework that can have a holistic analysis of value generation in a PE transaction. All these conceptual frameworks would seem to be based on the seminal article of Berg and Gottschalg (2003). To our knowledge, their article was the first attempt to shed lights on the value generation process as the:

Value generation $=$ Value creation $($ Primary levers+Secondary levers $)+$ Value capturing

These clear separation between concepts, are in line with all the presented results of this topic (Kaplan, 1989b, Acharya, Gottschalg, Hahn \& Kehoe, 2013, Ian, 2015, Puche, Braun \& Achleitner, 2015, etc.). They consist of a reading matrix to the complex interaction of these levers. Moreover, Berg and Gottschalg (2003) framework weas based on the allocation of these different levers that compose the value generated in a transaction through time (Acquisition, holding period and exit), but also through sources (intrinsic and external). The distinction between 
levers provides the organic composition of value generation during a PE transaction. Berg and Gottschalg present a comprehensive set of six levers that can be classified through the prior categorization:

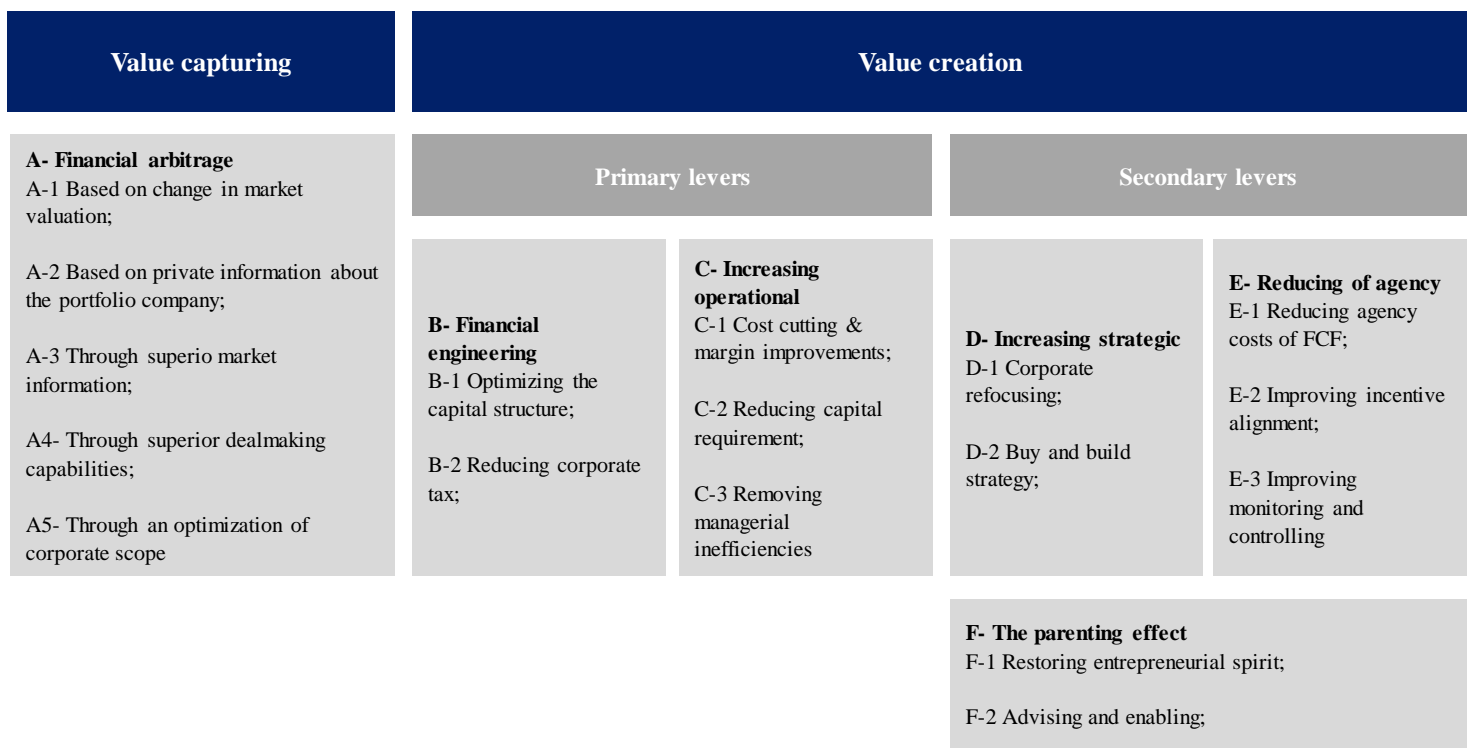

Source: Adapted from Berg and Gottschalg (2003)

Figure 3. Berg \& Gottschalg value generation breakdown

Hannus (2015), provide an actualized framework that propose another categorization standpoint of levers, mainly related to cultural and temporal levers, and propose a new way to analyze the sublevels. Even though these frameworks are considered as a solid background to understand the value creation process, they stay adapted to the context of developed countries, where the PE practice has carved its way to adapt to western economies specificities.

In relation to the international literature stream, seminal papers such as Achleitner, Braun and Engel (2011); Acharya et al. (2013) and Puche et al. (2015) have shown interest in this area and tried to quantify the importance of these levers and how they participate in value generation in a PE transaction. There results may be qualified as homogenous, since they bring out the same trend of levers contribution to value generation and set the financial levers contribution to the one third, while attributing the two thirds to operational levers (representing c. $40 \%$ to $60 \%$ depending on the targeted company size) and multiple expansion lever. The researchers also highlight the trend's shift from financial engineering extended in the process to focus on using more operational levers, in the last two decades, specially in the aftermath of the financial crisis. Indeed, such PE firms have found that more value could be generated through operational improvements (Wright, Gilligan \& Amess., 2009, Matthews, Bye \& Howland, 2009).

In relation with the literature that tackles the value creation levers used in a context of PE transaction within an emerging / in transition country, one must note that the literature is scarce. Fontaine (2014) and Taleb (2019), highlight that in a context characterized by a poor corporate governance and laid-back reporting procedures, an additional attention and effort needs to be done through governance and operational levers to meet the value creation. The proactive hands on approach is more suitable and focuses more on operational and strategic areas. The studies emphasis the importance of collaboration between the general partners and management teams to improve the business efficiency.

Regarding the financial levers, it seems that these levers use is quite shy and mitigate compared to the international practice (Taleb, 2019). The use of governance levers and operational levers predominate the way value is created among the PE transaction. In accordance with this fact, value capturing levers use, may not be clearly relied on in emerging / in transition countries. Instead, there is a clear influence that GPs try to put on their transaction through programing the exit strategy (Boufalah, 2018).

\section{Research Question}

Drawing from the literature, two main research question were formulated: 
i- What are the rational motivations of Moroccan PE firms that can lead to invest in a potential company?

ii- Within this PE investment process, how value generation process could be analyzed?

\section{Research Methodology}

As this paper is presented as a pilot study, we concentrate to give a complementary view of the existing framework for value generation in a PE transaction, but also, to present an adapted holistic framework for the Moroccan PE practice. Indeed, qualitative method can be very useful to comprehend an interacting process. Therefore, the qualitative method seems to be the most suitable method to cast a wide net, which can be vital for next studies.

This research is the first explanatory study of its type in the Moroccan background. We proposed a qualitative analysis that target a population of practitioners in the private equity industry that are actively engaged in PE transaction within the Moroccan landscape. We chose to conduct semi constructed interviews through an interview guide, that is structured to reflect and address our research questions. The first part aimed to tackle the Moroccan PE rational incentives that can explain how they select targeted companies, and the second part aimed to confront the PE firms to different value generation levers matrix issued from the literature and discuss how they assess the value generation / creation process.

Subsequently, since there is no prior official exhaustive database of PE firms operating in Morocco, we tried to compose a convenience sample of participants (4 GPs from four distinct PE firms), based on our discussion with AMIC managers. They propose us to select these exemplary PE firms that represent $50 \%$ of all transactions that occurred during the last three years. The purpose is to have each one representing a different strategy investment and three of them are representing regional / international PE houses investing and managing assets in Morocco. Only one PE firm is a bank affiliate. They all seek to invest in growth capital and to a lesser extent Leveraged Buyout. It should be noted that two of the selected PE firms are the ones that have achieved the largest number of LBOs transactions since the activity inception.

Vice president, directors and partners involved in the field of private equity were interviewed. The seniority levels were purposely chosen very high (in average 15 years of experience), in order to get experienced and pioneers' participant that can elucidate this phenomenon in Morocco.

Expert interviews had one major benefit over the use of other quantitative methods, in the way that the researcher is able to have more interaction and to get further insights even on other arising topics that were not planned initialy, which was interesting in an early stage of the topic understanding. Each part of our interview guide served to understand how Moroccan PE firms operate their investments and how they contribute to value creation at the transaction level.

Issued from our literature review, the pyramid of rational motivations and the matrix of value generation levers (Taleb, 2019) are considered as the fundamental points that determine the theoretical attributes to be contextualized. The purpose of this exploratory study is to be able to reduce the literature gap and the Moroccan practice. This expectation is motivated by (i) the level of development of the PE industry in Morocco. Undeniably, despite the advances made by the industry, Moroccan activity has not yet reached the same degree of maturity as developed countries. The legislative and economic framework is still underdeveloped so that the activity can have the same practices as the PE firms in developed countries, (ii) we believe that certain attributes are by nature not applicable to PE operations in Morocco (Taleb, 2019). This can be explained inter alia by the specificity of Moroccan companies and their legal-economic environment.

The contact list was provided through the AMIC association. A personalized email was sent to each participant to present the research project and to ask for a one-hour face to face meeting. To comfort and push the interviewee to participate, we insured that their identity would be held confidential. Under these circumstances, it should be noted that the 4 interviewees accepted to participate.

\section{Results \& Discussion}

Only one respondent occupied a vice president position. They all represent PE firms that were incorporated from the early 2000s. Only one PE firm was a bank affiliate. The four PE firms are currently holding 53 invested companies in their current porfolio.

The GP acknowledged that in the last five years, they were targeting companies in Morocco and Sub-Saharan countries. The participant PE firms are not specialized in a sector, they are referred as generalists. 


\subsection{Understanding the Local PE Investment Specificities}

It appears that the local PE firms are mostly interested to invest in elitist Moroccan SME that presents a high potential. This category of SMEs can fold under the classical definition of the Moroccan SME or not. The main aggregate that can permit PE firms to define theses companies is the turnover and its growth rate. Fundamentally, it is supposed to be superior or equal to MAD100 m.

In respect of this aspect, the average ticket invested remains weak [MAD20m-MAD60m] compared to other developed markets, specially regarding the first and the second fund generation. According to the interviewees, this tend to change in the subsequent generations, since PE firms advocated to change in 2011 the act 41-05, which used to force PE firms to allocate 50\% of their funds into SMEs that respect the Moroccan official definition.

With regards to the entrepreneurial scene, Moroccan PE firms face a lack of opportunities since major high potential SMEs are family governed companies that fragmented their conglomerate into small or medium entities for tax optimization purposes. This situation makes screening performing groups very difficult for the GPs and creates a dilution risk that can block any further transaction. In fact, this is one of the reasons that push most of the PE firms that invest in Morocco to take a minority share (30\% to $40 \%$ ).

\subsection{Understanding the Rational Motivation of PE Investment in the Moroccan Context}

It appears from the confrontation between the literature and the interviewees opinions that PE firms consider the direct selection criteria (4th criterion stratum of the presented pyramid in section 2.2) as the rational incentives that most determine their investment. The other incentives strata are tacit pre-investment motivations and tacitly considered in the selection criteria.

Therefore, based on the responses of the PE firms, we can propose the following criteria:

1- Management quality and background;

2- Financial and profitability criteria;

3- Market position;

4- Business model;

5- Capacity of exiting the deal;

6- Other criteria.

Regarding corresponding literature, this practical vision is partially shared. The literature shows that although the direct selection criteria are critical in the process, the other rational motivations (cf. pyramid in the literature) play an important role. As an example of this difference, one director confirmed that the economic environment, could not obstruct their investment, in case there is a competitive advantage that distinguish the targeted company. Hence, the direct selection criteria of the company are more likely to be considered as decisive.

On the other hand, the direct criteria that each of the participants presented were to some extent similar to the ones presented by Block et al. (2019) (cf. appendix 1). The main differences that raise through this assessment can mainly be presented as follows:

The participants argued that the quality of the management team is the cornerstone criteria that can be a prerequisite to the success of value generation process implementation. Since the Moroccan entrepreneurial environment is marked by the prevalence of a family ownership, the contemplated transaction structure is therefore often assimilated to a minority stake participation, as long as the entrepreneur / founder will not jeopardize his control on his company. Also, the quality of the management team can be analyzed through the lenses of agency theory framework. Participants confirmed that in this particular context, asymmetries of information issues may arise, so as the agency costs. Therefore, the value created subsequently cannot be achieved if the relation is not built on trust and interest alignment. In our context, an array of legal tools is deployed in the Sales Purchase Agreement (SPA), such as shareholders agreement to protect and incentive both parties. We assume that difference of importance between local acting PE firms and PE firms in other developing countries may be caused by the institutionalization and the democratization of modern governance structure within the targeted companies. Instead, in the context of a developed country the main concern is the revenue growth of the targeted company, which remains more objective and requires a pre-due diligence work.

- Once all interests aligned and a common ground of trust is founded, the PE firms acting in the Moroccan context can move to assess what they call the financial and profitability criteria, which includes the revenue growth criteria. The Moroccan practitioners argue that there is basically no difference between the financial criteria and that 
they are all equally important for them. On the contrary; Block et al., (2019) results show that it is worth distinguishing between "revenue growth" and "profitability" which presents two distinct interests between family offices and growth equity for example.

- The market position comes in third place and may be compared to some extent to the international scalability. According to the participants, the targets market position is an indicator that can give a clear view on the competitiveness of the company. According to two GPs, the acting local PE firms do not look to the market leader, rather, they are considering for instance, the 10th company in a given market, that may show a high potential of growth, with a realistic growth plan and an ambition. Regarding the literature, the international scalability, is considered when assessing the targeted company capacity to reach overseas markets and its deployability.

- The fourth important direct criteria to consider, is related to the targeted company business model. The participants believe that the business model must be sustainable and easy to evolve regarding the targeted company environment.

The fifth direct criteria is related to the capacity of the PE firm to see a possible exit to the transaction. Essentially relaying on the GPs experience, maximizing the value creation could never see the light if the exit could not be successful. Block et al. (2019) results, does not show this criterion, since the developed countries benefits from a dynamic economy and specially its financial markets.

- Finally, our participants presented other marginal criteria that have not got any consensus among them.

The different discussions have confirmed the importance to determine with care these criteria, as their impact could be decisive for the value creation process. In fact, all GPs confirmed that these direct criteria present for them a premise to underlying (or to direct) value creation levers Hence, the PE value generation process can be seen as a continuum process during the time.

\subsection{Understanding the PE Value Creation Process and Levers in the Moroccan Context}

The first outcome that appears interesting in relation with the PE firms view of value generation, is that the practitioners are more value creation oriented than value generation. The reasons behind this orientation is principally related to the Moroccan economy landscape and its financial markets efficiency. As already mentioned, in the absence of an efficient financial markets, it would be hard for PE investors to follow market trends by sectors and industries.

According to the participants feedbacks, PE professionals acting in Morocco lack to depict financial arbitrage opportunities and trends, to use them to leverage the value of a deal at the entry and / or the exit. This may be explained by (i) the lethargy of the financial markets but also by (ii) the emotional effect syndrome that entrepreneurs develop toward there owned companies. Considering the fact that many sellers are the founders of the company, they have an "emotional value" toward the targeted company, which can spoil any valuation method. To justify this value, PE investors are obliged to justify it with a premium that is hardly justifiable. This complicate the value maximization process through the deal and induce a greater implication of the GPs to work hands in hands with the management team, hence their importance during the investment rational.

Nevertheless, to work around this deficiency, PE firms use governance levers upstream the process (i.e. in the acquisition phase) to secure, recover and / or alleviate the premium paid at the exit. Even though, participants confirm that these levers, do not only apply to compensate the premium paid, but also to overcome the exist problems that they encounter in the Moroccan economy. Related to this matter, the same results have been confirmed by Boufalah (2018). Therefore, we can conclude that using the full proficiency of financial arbitrage to maximize the value creation, is not relevant in the Moroccan context.

This leads us to the importance of what was refered to as the governance or the management levers, that mainly relates to (i) the management team quality and (ii) motivations / incentives to realign the protagonists (i.e. buyer and the seller) interests. Although in literature review, these levers correspond to back up levers to the primary levers, it has been confirmed in these interviews that they were the most important and relevant to the entire process and specially in the context of a minority stake.

The management team quality appears to be characterized as a direct selection criterion, but also as a lever. The participants argued that reputational due diligence is even conducted to select and know who are the persons they will be tied to in the next coming years. The practitioners consider this as a lever since it's the management team who will be in charge of implementing and achieving the growth plan and thus the value creation. To ensure that these key men will stay on motivation board, PE firms insure to incentivize them through superior incentives mechanism, that 
can make them commit to the stated objectives.

The GPs affirmed that in the light of these conditions, they support the management team with insuring a modern governance system and leverage on the specialized counsels and boards to monitor and insure that the management team is diligent. The participants affirmed that they could be actively involved into operational challenges, to support and help implement the operational levers. According to the participants, achieving operational improvements can be done through:

(i) Operation profitability: i.e. boosting the revenues and cost cutting techniques to elevate the margins. All participants agreed that cutting the costs is not the better way to achieve it. A combined method could be more appropriate. They confirmed that their role could be also to influence the strategy of the firm (e.g. stopping a product line, refocusing on core activities, etc.), which can be already stated upstream in the SPA.

(ii) Managing the net working capital (NWC) and managing real estate assets: shaping the cash-flow through NWC is a specialty that PE firms adopt (Taleb, 2019). The participants confirmed the use of this lever to boost the cash-flow. However, it should be noted that 3 of 4 participants declared that this lever may sometimes be limited regarding the informal industry practice relating to this topic, that they can't overcome. As for the real estate assets that could be monetized, this can often be used, but was not recognized as a major lever that is relied on to create value.

From this point, PE firms try to foster the implementation of all these levers through the application of the 100 days program (Fontaine, 2014). This follows the idea that the more quickly the good habits and reporting systems are implemented, the more they can achieve abnormal returns and increase the IRR. All respondents confirmed that they are likely to give more than the $1 / 3$ of their time, during the first three months after the deals conclusion and this is a common lever that was used to boost the IRR.

Finally, concerning the financial levers, participants were mitigated regarding the use of an LBO scheme to boost value creation within the contest. According to them, the Moroccan context, is not favorable for these operations, knowing that (i) the average ticket is relatively low, in general PE firms acquire minority stake and (ii) the economic environment and local third parties (i.e. local banks) are likely to be less supportive to this exotic acquisition scheme. Still, PE practitioners confirmed that the financial levers are important and can be used through other forms after the closing to balance the capital structure of the acquired target.

To sum up, we can present the following adapted framework for value creation within a Moroccan PE transaction:



Figure 4. Proposed framework for value creation analysis within a Moroccan PE transaction 


\section{Conclusions, Implications and Limitations of Research}

\subsection{Conclusion}

In this paper, we tried to investigate rational motivations for PE firms to invest in a Moroccan context and how, based on these rational motivations, they seek and overlook to create value in these operations.

First, we find that the macroeconomic context of a country in transition could play a decisive role on how PE firms invest and run through the value creation process. This has been reflected in the difference of importance of direct selecting criteria that further the management aspect of the transaction and especially the management team.

Second, we tried to highlight the link between the PE investment process and the PE value creation process. As presented, the main links can be done between direct selecting criteria and value creation levers. In this context, we presented that majority of PE firms are essentially seeking to select high potential SMEs.

Third, our findings report that the PE firms acting in a Moroccan context fit within a value creation model rather than a value generation model. The participants presented that the most upcoming used levers are concentrating on Governance / Management levers, followed by the operational levers, which is the main trend confirmed by the literature (Achleitner, 2011, Puche et al., 2015, etc.). As for the financial levers, the results are quite mitigated and need more investigation. The LBO scheme is not systematically relied on to create value, which is a major difference with the literature strand that covers developed countries. Finally, the value capturing levers may be categorized as limping levers that can not be fully used specially at the entry. Rather, PE professionals like to define an exit strategy and bidding it upstream in the legal terms through the SPA.

The explanatory study is of interest to both professionals and academics. On the professional side, the paper gives an overlook of how PE firms acting in Morocco select their targets and what are the necessary pillars to contribute to value creation in the invested company. This contribution is done through the identified value creation levers and their appropriate usage. For academics, it can first be considered as a starting point for future research mainly in concern of (i) rational selection criterias that can be accurately tested through a thorough empirical testing with a wider sample and (ii) the organic composition of value creation within these transactions, i.e. what are the most important value creation lever(s) that a PE firm could use in the context of a Moroccan PE transaction?. In that sense, the proposed framework needs to be tested to confirm these findings in the Moroccan context.

Although this explanatory study was identified as a challenge, having access to the PE pratictionners was a difficult task regarding their tight agenda and the confidentiality matter that surround their investments. Without the assistance of the AMIC management, that would be more difficult. Also, the empirical selection methodology of the 4 PE firms could may be considered as a limit. Since it was based only on our discussions with the AMIC management and their statistics and knowing that they could be other transactions that are done by PE firms which are not based in Morocco, the question remains about the representativity of the sample. Nothwithstanding, we believe that the current sample is substantial and represent local and PE firms and regional PE firms implemented in Morocco.

\section{References}

Acharya, V., Gottschalg, O., Hahn, M., \& Kehoe, C. (2013). Corporatge Governance and Value Creation: Evidence from Private Equity. Review of Financial Studies, 26(2), 368-402. https://doi.org/10.1093/rfs/hhs117

Achleitner, A.-K., Braun, R., \& Engel, N. (2011). Value Creation And Pricing In Buyouts: Empirical Evidence From Europe And North America. Review of Financial Economics, 20, 146-161. https://doi.org/10.1016/j.rfe.2011.09.001

Berg, A., \& Gottschalg, O. (2005). Understanding Value Generation in Buyouts. Journal of Restructuring Finance, 2(1), 9-37. https://doi.org/10.1142/S0219869X05000221

Bernoth, K., Colavecchio, R., \& Sass, M/ (2010). Drivers of Private Equity Investment in CEE and Western European Countries. DIW Berlin Discussion Paper No. 1002. http://doi.org/10.2139/ssrn.1639446

Block, J., Fisch, C., Vismara, S., \& Andres, R. (2019). Private Equity investment criteria: An experimental conjoint analysis of venture capital, business angels and family offices. Journal of Corporate Finance. https://doi.org/10.1016/j.jcorpfin.2019.05.009

Boufalah, C. (2018). Défis à la sortie en capital investissement : Cas des fonds marocains. Thèse de Mastère (Master Thesis), Groupe ISCAE.

Cervaux, L. K. (2015). Analyse de la pertinence du modèle de financement du capital investissement. Thèse de 
Doctorat (PhD Thesis), Université de la Réunion. HAL Id: tel-01130136. Retrieved from https://tel.archives-ouvertes.fr/tel-01130136

Dawson, A. (2011). Private equity investment decisions in family firms: The role of human resources and agency costs. Journal of Business Venturing, 26(2), 189-199. http://doi.org/10.1016/j.jbusvent.2009.05.004

Fontaine, B. (2014). Value Generation in Emerging Markets Private Equity: Understanding the Model and value drivers at work. Master Thesis, HEC Paris.

Gompers, P. A., Gornall, W., Kaplan, S. N., \& Strebulaev, I. A. (2019). How Do Venture Capitalists Make Decisions?. Journal of Financial Economics. https://doi.org/10.1016/j.jfineco.2019.06.011

Groh, A., \& Liechtenstein, H. (2011). International allocation determinants for institutional investments in venture capital and private equity limited partnerships, International Journal of Banking, Accounting and Finance, 3(2-3), 176-206. https://doi.org/10.1504/IJBAAF.2011.041454

Hannus, S. (2015, August 5). The Price of Nothing - The Value of Everything: Towards an Understanding of Value Creation in Private Equity Buyouts. http:/doi.org/10.2139/ssrn.2612841

Irrmann, G. (2008). Le capital- investissement: Source de développement économique ou nouvelle forme de colonialisme? L'exemple du Maghreb. Observatoire du Management Alternatif. Cahier de recherche, HEC Paris.

Jensen, M. C (1989a). Active investors, LBOs and the privatization of bankruptcy. Journal of Applied Corporate Finance, 2(1), 35-44. https://doi.org/10.1111/j.1745-6622.1989.tb00551

Kaplan, S. N. (1989b). The Effects of Management Buyouts on Operating Performance and Value. Journal of Financial Economics, 24(2), 217-254. https://doi.org/10.1016/0304-405X(89)90047-0

Kaplan, S. N., \& Strömberg, P. (2009). Leveraged buyouts and private equity. Journal of Economic Perspectives, 23(1), 121-146. https://doi.org/10.1257/jep.23.1.121

Loos, N. (2005). Value Creation in Leverage Buyouts. Doctoral dissertations, University of St. Gallen, Graduate School of Business Administration, Economic Law and Social Sciences (HSG).

Lounes, M. (2012). Les principaux déterminants de la dynamique du capital-risque : modélisation et étude empirique sur données américaines, thèse d'Économie. Thèse de Doctorat (PhD Thesis). Laboratoire Erudite, Université Paris-Est Créteil Val de Marne.

Makhroute, M., \& Herradi, C. (2019). Les déterminants d'investissement et de désinvestissement des capital investisseurs : Cas des PME marocaines. Revue du Contrôle, de la Comptabilité et de L'Audit, 3(4), 190-205. Retrieved from http://www.revuecca.com/2019/03/numero-8-mars-2019.html

Matthews, G., Bye, M., \& Howland, J. (2009). Operational Improvement: The Key to Value Creation in Private Equity. Journal of Applied Corporate Finance, 21(3), 21-27. https://doi.org/10.1111/j.1745-6622.2009.00236.x

Millson, R., \& Ward, M. (2005). Corporate governance criteria as applied in private equity investments. South African Journal of Business Management, 36(1), 73-83. https://doi.org/10.4102/sajbm.v36i1.622

Puche, B., Braun, R., Achleitner, A. K. (2015). International Evidence on Value Creation in PE Transaction. Journal of Applied Corporate Finance, 27(4), Fall. https://doi.org/10.1111/jacf.12152

Rikato, M. (2014). Essays on Private equity: operating performance, investment selection success and costliness of placement agents. Doctoral dissertation, University of LJUBLJANA Faculty of Economy.

Rohamad, S., \& Idrissi, J. M. (2005). Le financement de l'innovation dans les PME marocaine : quel apport du capital investissement. Mémoire présenté pour l'obtention du diplôme du Cycle Supérieur de Gestion du Groupe ISCAE.

Taleb, T. A. (2019). La génération de la valeur dans les opérations de CI : proposition d'une revue de littérature adaptée aux pays émergents. Revue du Contrôle, de la Comptabilité et de L'Audit, 4(1), 80-105. Retrieved from http://www.revuecca.com/2019/06/numero-9-juin-2019-volume-4-numero-1.html

Wright, M., Gilligan, J., \& Amess, K. (2009). The economic impact of private equity: What we know and what we would like to know. Venture Capital an International Journal of Entrepreneurial Fiance, 11(1), 1-21. https://doi.org/10.1080/13691060802151887 


\section{Notes}

Note 1. AMIC: Association Marocaine des Investisseurs en Capital: AMIC is an independent non-profit association which was created in 2000 in order to: (i) Develop the Private Equity and Venture Capital industry in Morocco and internationally, (ii) Promote best practices, transparency and responsibility amongst professionals, (iii) Create the most favourable legal and fiscal environment by lobbying policy makers, (iv) Represent and defend its members' professional interests. (https://issuu.com/amicdocumentation)

Note 2. Original definition: «activité financière consistant à effectuer une prise de participation (sous forme de capital, de titres de créances convertibles ou non ainsi qu'en avances en comptes courants d'associés) pour une durée déterminée dans des entreprises non cotées ayant besoin de fonds propres ou de quasi-fonds propres, On utilise parfois indifféremment les termes «Capital Risque» (traduction de l'anglais «venture capital») et «Capital Investissement». Cependant, il semble plus judicieux de distinguer ces deux notions. Ici, l'expression «Capital Investissement» sera utilisée comme terme générique alors que le terme «Capital Risque» sera réservé au financement des entreprises en création»

Note 3. Original definition : «toute activité de prises de participation, temporaires et minoritaires dans des entreprises non cotées afin de dégager ultérieurement des plus-values... le capital investissement est une opération de fonds propres qui ne trouve sa rentabilité que dans la croissance et la capacité bénéficiaire de l'entreprise. Le capitalinvestissement est un placement à moyen ou long terme par lequel l'investisseur apporte une contribution active à la réussite des entreprises, en accompagnant leur croissance pour leur permettre de devenir les principales sociétés de leur secteur et ce, dans la perspective de faciliter leur introduction en bourse ou leur reprise par un tiers.» 